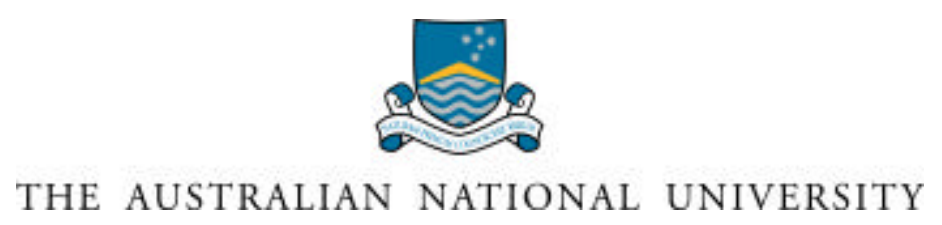

Working Paper Series in Finance 00-01

\title{
NEW INSIGHTS INTO THE IMPACT OF THE INTRODUCTION OF FUTURES TRADING ON STOCK PRICE VOLATILITY
}

\author{
Michael D. McKenzie*, Timothy J. Brailsford** and Robert W. Faff* \\ *School of Economics and Finance \\ RMIT \\ **Department of Commerce \\ Australian National University
}

JEL Classification

G10, G13

Keywords

Futures market; Volatility; Derivative trading; Individual share futures contracts

Last revision date:

May 2000

Contact author:

Michael McKenzie

School of Economics and Finance

RMIT

GPO Box 2476V

Melbourne 3001 AUSTRALIA

Telephone: 0399255897 (International +61 39925 5897)

Facsimile: 0399255986 (International +61 39925 5986)

Email: Michael.McKenzie@rmit.edu.au

The working paper series is for manuscripts in draft form. Comments are welcome and should be sent to the contact author. Please do not quote without permission.

(C) Copyright 2000 M.D. McKenzie, T. J. Brailsford and R.W. Faff 


\title{
NEW INSIGHTS INTO THE IMPACT OF THE INTRODUCTION OF FUTURES TRADING ON STOCK PRICE VOLATILITY
}

\author{
Michael D. McKenzie*, Timothy J. Brailsford** and Robert W. Faff* \\ *School of Economics and Finance \\ RMIT \\ ***Department of Commerce \\ Australian National University
}

\begin{abstract}
In this paper we examine whether, and to what extent, the introduction of trading in share futures contracts on individual stocks (ISF) has impacted on the systematic risk and volatility of the underlying shares. The use of ISF allows a unique experimental design that complements existing work on index futures. Our major findings are as follows. First, we find a general reduction in systematic risk on individual stocks following the listing of futures. Second, we find evidence of a decline in unconditional volatility. Third, we find mixed evidence concerning the impact on conditional volatility. Fourth, the introduction of futures is found to impact on the market dynamics, as reflected by a change in the asymmetric volatility response although the direction of that change is stock specific. In general, the results point to a number of features that are case-specific and provide new insights into the mixed results which are typical of existing studies.
\end{abstract}

Acknowledgments: The authors gratefully acknowledge the helpful comments from seminar participants at the National University of Singapore and two anonymous referees. 


\section{INTRODUCTION}

The impact of derivatives trading on the volatility of the underlying asset is a controversial issue among the financial commentators and market regulators. It has also proven to be a fertile area for empirical research among financial economists. One area of the literature has considered the introduction of options trading and in general the results provide no clear conclusion as to its effect. ${ }^{1}$ Some studies have found a reduction in volatility associated with the introduction of options trading [eg. Conrad (1989); Damodaran and Lim (1991); Ma and Rao (1988); Skinner (1989)]. Evidence to the contrary also exists however, insomuch as volatility was not affected following the introduction of options contracts [eg. Bollen (1998)]..$^{2}$

A second area of the literature has focussed on the impact of the introduction of futures contracts. $^{3}$ Again the evidence on whether and how the introduction of futures trading has effected the underlying asset is mixed. For example, a group of studies report a decrease (or no change) in volatility in the spot market following the introduction of futures [eg. Choi and Subrahmanyam (1994); Edwards (1988b); Moriarty and Tosini (1985); Robinson (1994)]. In contrast, other studies report an increase in volatility following the introduction of futures [eg. Antoniou and Holmes (1995); Damodaran (1990); Figlewski (1981); Harris (1989)].

\footnotetext{
${ }^{1}$ This literature is well represented by Ma and Rao (1988); Bansal, Pruitt and Wei (1989); Conrad (1989); Skinner (1989); Damodaran and Lim (1991); Watt, Yadav and Draper (1992) and Bollen (1998).

${ }^{2}$ In a recent paper, Sorescu (2000) argues that the mixed findings might be explained by a two-regime switching means model. Specifically, Sorescu's model produces an optimal switch date of 1981. Prior to this date positive abnormal returns are found for stocks with new listed options whereas after 1981, negative abnormal returns accrue for stocks with new listed options. Sorescu speculates as to three possible causes of the two regimes. First, index options were introduced in 1982 which may have had the effect of completing the market. Second, there were major market regulatory changes that took place around the early 1980s. Finally, a third explanation relates to the possibility that options have made it easier for informed traders to disseminate adverse information. Of note, these explanations are largely centred on the US market yet the research findings are not specific to any one national market.

${ }^{3}$ The literature can be broadly classified by the type of futures contracts studied: (a) commodity futures Working (1960); Powers (1970); Cox (1976); (b) financial futures - Figlewski (1981); Moriarty and Tosini (1985); Edwards (1988a); and (c) stock index futures - Stoll and Whaley (1987); Edwards (1988a and 1988b); Harris (1989); Damodaran (1990); Hodgson and Nicholls (1991); Bessembinder and Seguin (1992); Kamara, Miller and Siegel (1992); Lee and Ohk (1992); Choi and Subrahmanyam (1994); Robinson (1994); Antoniou and Holmes (1995); and Antoniou, Holmes and Priestley (1998).
} 
The issue remains controversial. In mid-1995, the Hong Kong Futures Exchange (HKFE) introduced a number of new futures contracts amid substantial controversy and legal battles. Similarly, new derivative products in Australia created much discussion with the Sydney Futures Exchange (SFE) and the Australian Stock Exchange (ASX) engaging in legal action over the introduction of new contracts. Settling the controversy has not generally been assisted by the inconsistency in the research findings.

Two schools of thought have emerged to explain the impact of futures contracts on the underlying asset. ${ }^{4}$ One view is that the introduction of futures trading increases the volatility of spot prices. For example, the inflow and existence of speculators in futures markets may produce destabilising forces, which among other things, create undesirable "bubbles" [see for example, Harris (1989); Edwards (1988a, 1988b); Stein (1987, 1989)]. Furthermore, an increase in volatility on expiration days is expected as investors attempt to close out their positions, settle contracts and trade on potential arbitrage opportunities. Generally, the financial press appears supportive of these arguments with claims that futures have raised voltility via the provision of low cost speculation opportunities, especially in the case of Japan [see Miller (1993)].

The alternative argument is that the introduction of futures contracts has led to more complete markets, enhancing information flows and thereby improving investment choices facing investors [see for example, Ross (1977); Hakansson (1978); Breeden and Litzenberger (1978); Arditti and John (1980)]. Futures contracts allow for new positions and expanded investment sets, or enable existing positions to be taken at lower costs. Futures trading may bring more (private) information to the market and allow for a quicker dissemination of information. In addition, futures contracts facilitate hedging so that less reliance need be placed on spot hedging strategies. Moreover, the transfer of speculative activity from the spot to the futures market may dampen spot market volatility. Indeed, Schwert (1990)

\footnotetext{
${ }^{4}$ We do not present a detailed review of the two competing views. The arguments are generally well known and reviewed in detail elsewhere [eg. Damodaran and Subrahmanyam (1992)].

${ }^{5}$ Although Damodaran and Subrahmanyam (1992) make the point that the spot market may become more attractive to investors and hence more liquid because arbitrage trading and contrarian trading strategies mitigate extreme price movements.
} 
shows that intraday index futures volatility is around 40 percent higher than intraday equity market volatility.

In this paper we re-examine the issue using a recently introduced set of futures contracts over individual shares. Individual share future (ISF) contracts, introduced in Australia in May 1994, present an attractive opportunity to conduct a study because of their unique characteristics. The introduction of ISFs was a world first for the SFE as such products had never traded previously on anything other than a trial basis. ${ }^{6,7}$ ISFs are futures contracts traded over specific equity shares and currently there are ten individual stocks on which ISFs are traded.

The study of the impact of an ISF contract on the underlying asset has several advantages. First, much of the analysis in the literature has been devoted to considering the impact of trading in market-wide instruments such as index contracts. Such studies are useful in assessing market-wide impact, but any effect in the underlying spot market can be dissipated across the many constituent assets, making it difficult to detect. Moreover, while an index futures contract is a tradeable instrument, the underlying spot market index cannot be directly traded. In the case of ISFs we can directly observe trading in the spot market. Further, studies that have examined the introduction of index futures have by definition only examined one event date, within a given market setting. In the case of ISF, there have been four separate introduction dates.

Second, studies of index futures have been concerned with changes in the market before and after listing. Many factors affect market prices (and volatility) and it has been impossible to separate out the effects of the introduction of index futures trading and general changes in market conditions. As ISFs are stock-specific however, we can control for market wide changes and so for example, we can examine changes in the beta risk of individual stocks. ${ }^{8}$

\footnotetext{
${ }^{6}$ For a detailed discussion of the introduction of ISF, see Brailsford and Cusack (1997).

${ }^{7}$ Of note, the introduction of futures contracts over individual stocks is an issue that continually surfaces in the USA (for example, see Wall Street Journal, 16 May 1994).

${ }^{8}$ Although note that the potential impact of derivatives introduction on beta risk has been investigated in the context of options [see for example, Klemkosky and Maness (1980); Trennepohl and Dukes (1979); Whiteside, Dukes and Dunne (1983); Skinner (1989) and Damodaran and Lim (1991)] and
} 
Finally, Antoniou, Holmes and Priestley (1998) argue that futures may change the role of market dynamics in terms of the way in which volatility is transmitted and therefore how information is incorporated into prices. The prior literature has generally restricted itself to testing changes in spot price volatility and has not considered whether reduced asymmetry for example, has resulted from futures trading. Such a restricted testing framework is overly limiting and may lead to inappropriate policy responses. As asymmetry is typically linked to news arrival, it can be examined more directly in the context of individual stocks. In summary, the study of ISFs complements the aggregate market studies involving index contracts.

The remainder of this paper is organised as follows. Section 2 contains details of the estimation method, while Section 3 describes the data. In Section 4 the results are presented and discussed. The final section concludes the paper.

\section{RESEARCH METHOD}

The mean return for each stock is modeled using an augmented market model, which incorporates a dummy variable designed to capture the impact of the introduction of each ISF on both the intercept and the slope coefficients, ie.: ${ }^{9}$

$$
\mathrm{R}_{\mathrm{it}}=\phi_{0}+\phi_{1} \mathrm{D}_{1}+\phi_{2} \mathrm{R}_{\mathrm{Mt}}+\phi_{3} \mathrm{D}_{1} \mathrm{R}_{\mathrm{Mt}}+\varepsilon_{\mathrm{t}}
$$

where $\mathrm{R}_{\mathrm{t}}$ is the log price relative of the underlying stock $i$ at time period $t ; \mathrm{D}_{1}$ is a dummy variable which takes on a value of unity following the introduction of ISF on that stock; $\mathrm{R}_{\mathrm{Mt}}$ is the $\log$ price relative of the stock market index; and $\varepsilon_{\mathrm{t}}$ is the standard error term.

\footnotetext{
indirectly through index futures [see for example, Martin and Senchack (1989, 1991); Damodaran (1990) and Kan and Tang (1999)].

${ }^{9}$ There is little need for a thin-trading adjustment in the mean equation since the stocks on which ISF are traded tend to be the most frequently traded and largest stocks in the Australian market.
} 
Following Lee and Ohk (1992), Robinson (1994), Antoniou and Holmes (1995) and Antoniou, Holmes and Priestley (1998), we perform our analysis within the framework of the generalised autoregressive conditional heteroskedasticity (GARCH) class of models. ${ }^{10}$ The standard GARCH model relates the conditional variance to the lagged squared error term and past conditional variances. More recent studies in this area have extended their scope to consider the impact of listings of futures contracts on how the market responds to 'news'. Futures trading may potentially impact on these market dynamics. Following Antoniou et al. (1998), market dynamics related to the transmission of news may be responsible for asymmetries in the volatility response mechanism. ${ }^{11}$ Moreover, in the spirit of Lee and Ohk (1992), dummy variables are included for individual terms. Thus, to test the impact of the introduction of ISF, the GARCH model is modified along the lines of the Threshold ARCH (TARCH) model of Zakoian (1994). Hence, the augmented model may be specified as:

$$
\mathrm{h}_{\mathrm{t}}=\alpha_{0}+\alpha_{1} \varepsilon_{\mathrm{t}-1}^{2}+\alpha_{2} \mathrm{D}_{1} \varepsilon_{\mathrm{t}-1}^{2}+\beta_{1} \mathrm{~h}_{\mathrm{t}-1}+\beta_{2} \mathrm{D}_{1} \mathrm{~h}_{\mathrm{t}-1}+\gamma_{1} \mathrm{D}_{1}+\gamma_{2} \varepsilon_{\mathrm{t}-1}^{2} \mathrm{D}_{2}+\gamma_{3} \varepsilon_{\mathrm{t}-1}^{2} \mathrm{D}_{3}
$$

where $D_{1}$ is a dummy variable that takes on a value of unity following the introduction of ISF on the stock; and $D_{2}\left(D_{3}\right)$ is a dummy variable which takes on a value of unity if the error is negative in the pre (post) ISF introduction period and zero otherwise.

In mean equation (1), any impact of ISF introduction on the systematic risk of the underlying stock is captured by the $\phi_{3}$ coefficient. ${ }^{12}$ A positive coefficient on $\phi_{3}$ indicates increased beta risk in the post-ISF period. ${ }^{13}$ That is, the introduction of futures trading has increased the sensitivity of the stock to market-wide movements. Alternatively, a negative coefficient on $\phi_{3}$ indicates reduced beta risk in the post-ISF period. The specification of conditional

\footnotetext{
${ }^{10}$ The ARCH model is now commonly used to capture time-varying volatility dynamics in asset returns. See Bollerslev, Chou and Kroner (1992) for a review.

${ }^{11}$ It has been suggested that the traditional explanation of the leverage effect for asymmetry (see Nelson 1990a,b) cannot fully account for observed asymmetry in the market [Bekaert and Wu (2000)].

${ }^{12}$ For completeness, the dummy variable on the intercept is used to capture any shift in the constant term. The model was also estimated with a common intercept term for the pre-and post-listing periods, and the results are robust to this variation in experimental design.

${ }^{13}$ Note that this argument assumes that any impact on the individual stock's volatility does not have a corresponding impact on the volatility of the aggregate market or relevant covariance term; or more generally, that any changes in these variables have an offsetting effect.
} 
variance equation (2) allows us to examine the unconditional stock price volatility through the $\gamma_{1}$ coefficient. A positive $\gamma_{1}$ coefficient indicates increased unconditional volatility in the post-ISF period, whereas a negative $\gamma_{1}$ coefficient indicates decreased unconditional volatility in the post-ISF period. ${ }^{14}$

Conditional variance equation (2) also allows for a number of tests of the impact of futures trading on conditional stock price volatility. We may individually test the ARCH term or the GARCH term. However, in the context of the GARCH framework it is more appropriate to test the joint null hypotheses of no impact on the conditional variance specification, $\left(\alpha_{2}=\beta_{2}=0\right)$, against the alternative of at least one coefficient being non-zero. Furthermore, we may test the joint hypothesis that the ISF introduction has had no impact on volatility per se, $\left(\gamma_{1}=\alpha_{2}=\beta_{2}=0\right)$ against the alternative of at least one coefficient being non-zero. In this case, the test examines both unconditional and conditional volatility effects.

Finally, we can also test whether futures trading has changed the role of market dynamics in terms of the way in which volatility is transmitted and therefore how information is incorporated into prices. Antoniou et al. (1998) find in their empirical analysis of six markets that there is a change in asymmetric responses to volatility pre- and post-futures. In contrast to Antoniou et al. (1998), we simultaneously incorporate both issues of asymmetry and the potential impact of futures introduction on the level of volatility into the one model.

In equation (2) it can be seen that when the coefficients on $D_{2}$ and $D_{3}$ are jointly equal to zero the model collapses in to the symmetric version of the GARCH model. A negative shock in the pre-listing period (ie. $\mathrm{D}_{2}=1$ ) or in the post-listing period (ie. $\mathrm{D}_{3}=1$ ) can generate an asymmetric response. The nature of that response depends on the sign associated with the $\gamma_{2}$ and $\gamma_{3}$ terms. Where $\gamma_{2}$ or $\gamma_{3}>0\left(\gamma_{2}\right.$ or $\left.\gamma_{3}<0\right)$, the model produces a larger (smaller) response for a negative shock compared to a positive shock of equal

\footnotetext{
${ }^{14}$ As discussed later, Australian ISF were listed on four separate dates and on three of these dates, at least three ISF contracts were jointly listed. Where joint listings occur in this fashion, potential problems in inference arise due to cross-sectional dependence among contemporaneous measurements of returns and variances [see, for example, Bollen (1998)]. To allow for this possibility, the returns and variances of each stock which had an ISF introduced on the same date are also modelled using a Multivariate
} 
magnitude. Accordingly, the impact of ISF listing on this asymmetry feature can be assessed through a comparison of $\gamma_{2}$ and $\gamma_{3}$.

\section{DATA}

Australia currently has ISF contracts traded on ten individual stocks. ${ }^{15}$ Each ISF contract represents 1,000 shares of the underlying stock. The contracts are available on a threemonth expiry cycle with the two near-dated contracts listed for trading at any time. Table 1 lists the date of introduction by the SFE of each ISF and this information forms the basis for the creation of the pre- and post-ISF dummy variables used in the estimation procedure. Of note, options are traded on all ten stocks which were listed prior to the introduction of ISF. Hence, there is a natural control established which allows for an examination of futures in the presence of options.

\section{[TABLE 1 ABOUT HERE]}

With a sample of ten stocks on which ISF contracts have been introduced, it is possible that factors other than the introduction of futures may affect the variables considered in each of the hypothesis tests. For example, market-wide changes may have occurred around the time of the ISF introduction date that altered the dynamics of the market. Our tests may erroneously attribute such a change, if it occurred, to the introduction of ISF. Thus, it is necessary to implement a control procedure. Such a control is undertaken by constructing a control portfolio of similar stocks that did not have an ISF introduced. Where the ten stocks behave differently to the control portfolio, then the conclusions drawn with respect to the impact of the introduction of the ISF contracts are strengthened.

GARCH (M-GARCH) model [see, for example, Bera and Higgins (1993, pp.342-347)]. The results of this analysis are robust to this experimental variation but are not reported to conserve space.

${ }^{15}$ The stocks are Australia and New Zealand Banking Group (ANZ), Broken Hill Proprietary Ltd (BHP), Rio Tinto (RIO), Fosters Brewing Group (FBG), Mount Isa Mines (MIM), National Australia Bank (NAB), Newscorp (NCP), Pacific Dunlop (PDP), Westpac Banking Corporation (WBC), and Western Mining Corporation (WMC). An eleventh ISF for BTR Nylex was introduced on the 26 September 1994 and subsequently suspended in September 1995 and delis ted in November 1995 due to takeover activity. As this ISF is no longer traded it was excluded from the analysis. 
To this end, a control portfolio was constructed as follows. Individual control stocks are selected to match the ISF stocks on the basis of both industry grouping and market capitalisation. ${ }^{16}$ Further, as all stocks on which ISF are listed have options traded, the control stocks were also selected such that they also have options traded. Given that ISF contracts have been introduced on the largest and most heavily traded companies in the Australian market, the choice of control stock was typically the next largest participant in the industry. For example, the banks included in this study (ANZ, NAB and WBC) represent three of the 'big four' banks in Australia and so the choice of the fourth bank (Commonwealth Bank) as the banking sector control stock was obvious. ${ }^{17}$ An equally weighted portfolio of these control stocks was constructed which would act as the control benchmark.

Daily closing stock prices are sourced from the Securities Industry Research Centre of Asia-Pacific core research database, over the period 1 January 1990 to 30 June 1998 producing a total of 2,144 observations per stock. These prices are adjusted for dilution occurring due to capitalisation changes and exclude exchange holidays on the domestic market. ${ }^{18}$ The market portfolio is proxied by the All Ordinaries Accumulation Index.

Continuously compounded percentage returns for each stock and the control portfolio are estimated as the log price relative and Table 2 presents a set of basic descriptive statistics, divided into two sub-periods, namely, a pre-ISF listing period and a post-ISF listing period. Of greatest interest in this table are the figures obtained for the standard deviation estimates, providing an initial view of volatility for each stock in our sample. In the pre-ISF listing period we fnd that BHP and NAB provide the lowest standard deviations, while NCP, MIM and FBG provide the highest standard deviations. In the post-ISF listing period BHP and NAB again produce the lowest standard deviations, although they have increased slightly, whereas NCP and FBG show considerable reductions in standard deviation from

\footnotetext{
${ }^{16}$ Of course, a general problem with a control group is that the distinguishing feature between the two groups, in the case the individual futures contract, may be endogenous such that it may depend on stock characteristics in the pre-listing period.

${ }^{17}$ The control stocks are Comalco, Lion Nathan, North, PBL, Southcorp and the Commonwealth Bank for the Other Metals (MIM and WMC), Alcohol and Tobacco (FBG), Diversified Resources (BHP and RIO), Media (NCP), Diversified Industrials (PDP) and Banking (ANZ, NAB and WBC) sectors, respectively.
} 
the pre-ISF to the post-ISF periods. Similar to earlier studies in this area, we initially conduct equality of variance tests. These tests reveal significant differences between the variance pre- and post-ISF listing for eight of the ten stocks. ${ }^{19}$ This evidence suggests that some change has taken place over the relevant period and thus motivates further investigation.

\section{[TABLE 2 ABOUT HERE]}

\section{RESULTS}

Each individual stock return series as well as returns on the control portfolio are modeled using equation (1) with the conditional variance specified as equation (2). The Berndt-HallHall-Hausman optimisation algorithm is employed to obtain maximum likelihood estimates of each of the coefficients in the mean and variance equations and the results are presented in Table 3. The standard diagnostic tests of the residuals from the model confirm the absence of any further $\mathrm{ARCH}$ effects suggesting an appropriate model specification. That is, the squared standardised residuals of this modified $\operatorname{GARCH}(1,1)$ model reveal a general absence of significant autocorrelation which Bollerslev and Mikkelsen (1996) argue indicates the model has captured the ARCH effects. Further, the standardised residuals are largely IID N(0,1) which again supports the model specification.

\section{[TABLE 3 ABOUT HERE]}

\subsection{Systematic Risk}

First, consider the mean equation results reported in Table 3. The beta risk estimates are represented by $\phi_{2}$ (the pre-ISF beta risk estimate) and $\phi_{3}$ (the post-ISF increment to beta risk relative to the $\phi_{2}$ benchmark). All but one pre-ISF beta is estimated at greater than unity. When we consider the sign and significance of the beta risk change coefficient, $\phi_{3}$, we find that in five (half of the) cases there has been a significant decline in beta risk in the post-

\footnotetext{
${ }^{18}$ Some shares are traded overseas on days the Australian market was closed.

${ }^{19}$ The equality of variance tests include the F-test, Siegel-Tukey, Bartlett, Levene and Brown-Forscythe tests. The results are consistent across all tests.
} 
ISF listing period and a decline, albeit insignificant, in a further three cases. The largest decline occurs for FBG with a fall in beta of around $30 \%$.

The decline in beta risk may be due to market-wide trends. Hence, we turn to the control portfolio. In all cases the beta for the control portfolio increases, and significantly so in two cases. These results contrast with the individual stock findings above. Hence, the evidence is consistent with a decline in systematic risk for the ISF stocks.

\subsection{Unconditional Volatility}

Next, consider the variance equation results reported in Table 3. Recall that the unconditional volatility change coefficient is given by $\gamma_{1}$. Eight of the ten stocks reveal a negative coefficient which is significant in seven cases, thereby supporting a decline in volatility in the post-listing period. Of the remaining two cases, only one is significant (NCP).

In Panels $\mathrm{A}$ and $\mathrm{D}$ we see that the control portfolio also produces a significantly negative $\gamma_{1}$ coefficient. However, in Panel B the control portfolio $\gamma_{1}$ coefficient is statistically insignificant which contrasts to the finding of a significant negative coefficient for all three ISF stocks over that test period. A similar result occurs for the third test period reported in Panel C where the control portfolio coefficient is positive while all three ISF stocks exhibit a negative coefficient. Hence, there is again a difference between the individual ISF results and the control portfolio, thus re-enforcing the earlier conclusion favouring a decline in unconditional volatility. 


\subsection{Conditional Volatility}

From Table 3, there is some evidence of a decline in the ARCH and GARCH terms in the post-ISF period. However, the focus is on joint tests of the parameters. Test statistics for the null hypothesis of joint equality to zero of the change in ARCH and GARCH terms are presented in the first column of Table 4. From this table, the Wald test $p$-values show that the null hypothesis of no change is rejected for five of the stocks at the $5 \%$ level, with a further three significant at the $10 \%$ level. The exceptions are RIO and PDP. The Wald test of null hypothesis for the control portfolio is significant only when tested against the May 1994 date. For the other three dates, the null hypothesis is accepted for the control portfolio. This evidence suggests that the conditional variance for most of the stocks underwent some form of change around the date of the ISF introduction. As this change was not generally in evidence for the control portfolio, there is support for the change being induced by the introduction of futures trading.

\section{[TABLE 4 ABOUT HERE]}

The analysis can be extended to consider the impact of the futures trading on both the conditional and unconditional variance by testing that the ISF introduction has had no (joint) effect on any variance equation parameters, ie. $\gamma_{1}=\alpha_{2}=\beta_{2}=0$. The outcome of the Wald test for the null hypothesis is presented in the second column of Table 4 and the results indicate that the relevant coefficients in the variance equation have significantly changed in eight of ten stocks at the 5\% level (and NCP is again marginal at the $10 \%$ level). RIO is the sole exception and ISF trading appears to have had no effect on the conditional variance for this stock. One possible explanation of this could be due to the fact that the futures contracts on RIO are very thinly traded.

The joint test of this null hypothesis for the control portfolio indicates that for three of the four dates tested, a significant change in the variance equation is found. Thus, while the change to the conditional variance parameters seems largely limited to the stocks on which ISF are traded, when we consider a joint test of a change to both the conditional and 
unconditional variance parameters, the control portfolio appears to mimic the individual share results more closely. Hence, support for a futures-induced change is weakened.

\subsection{Asymmetry Hypothesis}

The $\gamma_{2}$ coefficient in (2) captures asymmetry in the pre-ISF listing period. Table 3 reveals limited evidence that responses are asymmetric in their nature with only four of ten stocks (NCP, FBG, PDP, BHP) producing statistically significant pre-ISF listing asymmetry coefficients. Of these, the first three cases are positive, suggesting that negative shocks elicit a larger response compared to positive shocks of an equal magnitude. Interestingly, Panels $\mathrm{A}$ and $\mathrm{B}$ reveal that the control portfolio also produces evidence of asymmetry in the preISF period.

The impact of ISF introduction on this asymmetry may be assessed by considering the $\gamma_{3}$ coefficient which captures the nature of any bias in the post-ISF listing period. Table 3 reveals a mixture of evidence of asymmetric market responses with four of the ten stocks (BHP, NAB, MIM, WMC) producing statistically significant post-ISF listing asymmetry coefficients. Of these four, only BHP produced a significant asymmetry term in the prelisting period, although the sign has reversed from negative to positive. For the remaining three cases, MIM and WMC are positive, while NAB exhibits a negative coefficient suggesting that negative shocks elicit a smaller response compared to positive shocks of an equal magnitude. In contrast, none of the control portfolios produce a statistically significant asymmetry coefficient in the post-ISF period. It is dso worth noting that three stocks (WBC, ANZ and RIO) show no evidence of an asymmetric volatility response in either period.

It is possible to test whether these pre- and post-ISF asymmetry coefficients are significantly different from each other using a Wald test of the null hypothesis, ie. $\gamma_{2}=\gamma_{3}$. The results of this test are presented in the final column of Table 4 and indicate that for BHP, NAB, NCP and FBG, the test statistic rejects the equality hypothesis. As each of these stocks experience a sign reversal between periods, the interpretation of these results is difficult. We 
can say that the nature of the asymmetry has changed for some stocks as a result of the introduction of ISF, however, whether that asymmetry has increased or decreased is not clear due to the sign reversal. Thus, while the introduction of ISF appears to have had an impact on the asymmetry of volatility, the effect is not uniform across the stocks. Moreover, there is some doubt over the cause being linked to ISF introduction in the case of BHP, $\mathrm{NAB}$ and $\mathrm{NCP}$, since a similar decline in asymmetry is found for the associated control portfolio.

\section{CONCLUSION}

This paper investigates whether and to what extent the introduction of futures trading has had an impact on the volatility of the underlying asset. The existing literature has produced evidence on this issue which is mixed. On the one hand, there is evidence consistent with the assertion that (for example) speculators in futures markets produce destabilising forces. The policy implications of this type of behaviour suggest regulation of the market, assuming that regulators can devise a sufficiently targeted means of addressing the problem that minimises any unintended consequences. On the other hand, evidence has also been found which supports a more favourable view of futures trading in which the introduction of futures trading leads to more complete markets, enhanced information flows and, thus improved investment choices for investors. The implication of this hypothesis suggests that regulation is inappropriate and costly. Thus, the policy implications of the literature stand in stark contrast with each other.

One noteworthy feature of this study is that, in contrast to the extant literature for equities which has exclusively considered market-wide instruments, in this paper we focus on the impact of the introduction of individual share futures contracts on the specific equity on which the value of the futures contract is based. The use of an indvidual share future contract allows us to impliment a research design which not only complements existing aggregate market studies which typically consider the mean return and variance, but also extends it into the realm of considering changes in the systematic risk of individual stocks. 
The outcome of the analysis can be summarised as follows. First, we find a general reduction in systematic risk in post-ISF listing periods for the stocks which have futures contracts traded and this trend was not evident in a control portfolio. Second, we find evidence of a decline in unconditional variance, which is not found to the same extent in the control portfolio. Third, we find evidence of some changes in the dynamics by which the conditional variance evolves. Finally, there is some evidence to support a change in the asymmetric response in individual stock returns following futures listing, although this evidence is not strong and difficult to interpret given conflicting sign changes. We find that there is no clear and consistent response across all stocks in this regard.

These results demonstrate that different institutional settings or different sample periods are generally not the reason for different findings in the literature. Rather we speculate that trading conditions associated with individual stocks (or markets), such as liquidity are the more likely cause of different findings. This is a matter of ongoing research. Moreover, the results are indicative that markets behave differently depending on the surrounding circumstances.

Overall, the results presented in this paper suggest that the issue is more complex than may have been first thought. Derivatives and volatility are unlikely to have such a direct link as some commentators would suggest. Antoniou, Holmes and Priestley (1998) argue that exclusively focusing on the two competing views is overly simplistic and potentially suboptimal from a policy perspective. Our results are supportive of their argument. 
TABLE 1

Names and Listing Dates for Australian Individual Share Futures (ISF)

\begin{tabular}{|l|c|c|}
\hline \multicolumn{1}{|c|}{ Company Name } & Code & Listing Date \\
\hline 1. Broken Hill Proprietary Ltd & BHP & 16 May, 1994 \\
\hline 2. National Australia Bank & NAB & 16 May, 1994 \\
\hline 3. Newscorp & NCP & 16 May, 1994 \\
\hline 4. Mount Isa Mines & MIM & 26 September, 1994 \\
\hline 5. Westpac Banking Corporation & WBC & 26 September, 1994 \\
\hline $\begin{array}{l}\text { 6. Western Mining Corporation } \\
\text { Banking Group }\end{array}$ & WMC & 26 September, 1994 \\
\hline $\begin{array}{l}\text { 7. Rio Tinto } \\
\text { 9. Fosters Brewing Group }\end{array}$ & FBG & 13 March, 1995 \\
\hline 10. Pacific Dunlop & PDP & 13 March, 1995 \\
\hline
\end{tabular}


TABLE 2

Descriptive Statistics of Underlying Daily Returns on Stocks on which Individual Share Futures are Listed and Associated Control Portfolios

\begin{tabular}{|c|c|c|c|c|c|c|c|c|c|c|c|c|c|c|}
\hline \multicolumn{15}{|c|}{ Panel A: Pre-ISF Listing Period } \\
\hline & \multicolumn{4}{|c|}{2 Jan 1990 to 15 May 1994} & \multicolumn{4}{|c|}{ 2 Jan 1990 to 25 Sept 1994} & \multicolumn{4}{|c|}{2 Jan 1990 to 12 Mar 1995} & \multicolumn{2}{|c|}{$\begin{array}{l}2 \text { Jan } 1990 \text { to } \\
17 \text { Oct } 1995 \\
\end{array}$} \\
\hline & BHP & $\mathrm{NAB}$ & NCP & Control & MIM & WBC & WMC & Control & ANZ & RIO & FBG & Control & PDP & Control \\
\hline Mean & 0.000564 & 0.000527 & 0.000879 & 0.000453 & 0.000195 & -0.000202 & 0.000175 & 0.000383 & -0.000127 & 0.000289 & -0.000477 & 0.000314 & -0.000263 & 0.000406 \\
\hline Median & 0.000000 & 0.000000 & 0.000000 & 0.000000 & 0.000000 & 0.000000 & 0.000000 & 0.000000 & 0.000000 & 0.000000 & 0.000000 & 0.000000 & 0.000000 & 0.000000 \\
\hline Maximum & 0.045257 & 0.053885 & 0.328960 & 0.165947 & 0.102809 & 0.066615 & 0.068993 & 0.165947 & 0.084770 & 0.072103 & 0.118716 & 0.165947 & 0.058905 & 0.165947 \\
\hline Minimum & -0.056089 & -0.078840 & -0.223603 & -0.052039 & -0.070769 & -0.095310 & -0.068803 & -0.052039 & -0.090573 & -0.062520 & \begin{tabular}{|c|}
-0.098440 \\
\end{tabular} & -0.052039 & -0.072245 & -0.052039 \\
\hline \begin{tabular}{|l|} 
Std Dev \\
\end{tabular} & 0.011957 & 0.011818 & 0.028580 & 0.010894 & 0.019140 & 0.015810 & 0.016526 & 0.010818 & 0.016596 & 0.013675 & 0.020299 & 0.010706 & 0.013774 & 0.010508 \\
\hline Skewness & 0.006152 & -0.391395 & 0.952731 & 3.122808 & 0.207646 & -0.286126 & 0.085243 & 2.935835 & 0.015857 & 0.160707 & 0.119151 & 2.754868 & 0.072074 & 2.607450 \\
\hline Kurtosis & 4.224003 & 6.248927 & 26.86262 & 51.86335 & 4.261267 & 5.573193 & 3.991236 & 49.41435 & 5.352158 & 4.600929 & 6.262089 & 47.23528 & 5.061867 & 45.64335 \\
\hline
\end{tabular}

\begin{tabular}{|c|c|c|c|c|c|c|c|c|c|c|c|c|c|c|}
\hline \multicolumn{15}{|c|}{ Panel B: Post-ISF Listing Period } \\
\hline & \multicolumn{4}{|c|}{16 May 1994 to 30 June 1998} & \multicolumn{4}{|c|}{26 Sept 1994 to 30 June 1998} & \multicolumn{4}{|c|}{13 Mar. 1995 to 30 June 1998} & \multicolumn{2}{|c|}{$\begin{array}{l}18 \text { Oct } 1995 \text { to } \\
30 \text { June } 1998\end{array}$} \\
\hline & BHP & NAB & NCP & Control & MIM & WBC & WMC & Control & ANZ & $\mathrm{RIO}$ & FBG & Control & PDP & Control \\
\hline Mean & -0.000136 & 0.000573 & 0.000736 & 0.000439 & -0.001272 & 0.000889 & -0.000541 & 0.000526 & 0.001037 & 0.000211 & 0.000833 & 0.000654 & -0.000318 & 0.000534 \\
\hline Median & -0.000557 & 0.000793 & 0.000000 & 0.000266 & 0.000000 & 0.001162 & 0.000000 & 0.000321 & 0.001692 & 0.000000 & 0.000000 & 0.000689 & 0.000000 & 0.000902 \\
\hline Maximum & 0.078432 & 0.044348 & 0.085495 & 0.075590 & 0.113329 & 0.051225 & 0.097838 & 0.075590 & 0.091952 & 0.076633 & 0.074108 & 0.075590 & 0.066166 & 0.075590 \\
\hline Minimum & -0.060961 & -0.055104 & \begin{tabular}{|l|}
-0.077558 \\
\end{tabular} & -0.066417 & -0.145852 & -0.063974 & -0.079901 & \begin{tabular}{|l|}
-0.066417 \\
\end{tabular} & -0.070643 & -0.120016 & -0.048575 & -0.066417 & -0.125163 & -0.066417 \\
\hline \begin{tabular}{|l|} 
Std Dev \\
\end{tabular} & 0.013151 & \begin{tabular}{|l|}
0.012140 \\
\end{tabular} & \begin{tabular}{|l|}
0.016957 \\
\end{tabular} & 0.009604 & 0.021831 & 0.013304 & 0.017678 & \begin{tabular}{|l|}
0.009575 \\
\end{tabular} & 0.015269 & 0.013285 & 0.013762 & 0.009586 & 0.016823 & 0.009793 \\
\hline \begin{tabular}{|l} 
Skewness \\
\end{tabular} & 0.268466 & \begin{tabular}{|l|}
-0.460154 \\
\end{tabular} & \begin{tabular}{|l|}
0.467520 \\
\end{tabular} & \begin{tabular}{|l|}
-0.036369 \\
\end{tabular} & -0.170721 & \begin{tabular}{|l|}
-0.198819 \\
\end{tabular} & 0.248598 & \begin{tabular}{|l|}
-0.028818 \\
\end{tabular} & -0.128652 & -0.570001 & 0.044389 & -0.012158 & -0.870219 & -0.025198 \\
\hline Kurtosis & 5.474368 & 5.014947 & 5.393826 & 9.035892 & 7.892617 & 4.280864 & 5.471216 & 9.638762 & 5.683213 & 12.28749 & 4.238520 & 10.40018 & 9.579049 & 11.24201 \\
\hline
\end{tabular}


TABLE 3

Estimated Augmented Market / Generalised TARCH Model Coefficients

This table reports the estimated coefficients (absolute values of $t$-statistics in parentheses) for the model:

$$
\begin{aligned}
& \mathrm{R}_{\mathrm{it}}=\phi_{0}+\phi_{1} \mathrm{D}_{1}+\phi_{2} \mathrm{R}_{\mathrm{Mt}}+\phi_{3} \mathrm{D}_{1} \mathrm{R}_{\mathrm{Mt}}+\varepsilon_{\mathrm{t}} \\
& \mathrm{h}_{\mathrm{t}}=\alpha_{0}+\alpha_{1} \varepsilon_{\mathrm{t}-1}^{2}+\alpha_{2} \mathrm{D}_{1} \varepsilon_{\mathrm{t}-1}^{2}+\beta_{1} \mathrm{~h}_{\mathrm{t}-1}+\beta_{2} \mathrm{D}_{1} \mathrm{~h}_{\mathrm{t}-1}+\gamma_{1} \mathrm{D}_{1}+\gamma_{2} \varepsilon_{\mathrm{t}-1}^{2} \mathrm{D}_{2}+\gamma_{3} \varepsilon_{\mathrm{t}-1}^{2} \mathrm{D}_{3}
\end{aligned}
$$

where $\mathrm{R}_{\mathrm{it}}$ is the log price relative of the underlying equity of stock $i$ (on which an ISF has been introduced) at time period $t$; $\mathrm{D}_{1}$ is a dummy variable which takes on a value of unity following the introduction of that share's ISF; $\mathrm{D}_{2}\left(\mathrm{D}_{3}\right)$ is a dummy variable which takes on a value of unity if the mean equation error term is negative in the pre (post) ISF introduction period and zero otherwise and $\mathrm{R}_{\mathrm{Mt}}$ is the log price relative of the Australian stock market index. The model is also estimated at each date for an equally weighted

\begin{tabular}{|c|c|c|c|c|c|c|c|c|c|c|c|c|}
\hline \multirow[b]{2}{*}{ Stock } & \multicolumn{4}{|c|}{ Mean Equation } & \multicolumn{8}{|c|}{ Variance Equation } \\
\hline & $\phi_{0}$ & $\phi_{1}$ & $\phi_{2}$ & $\phi_{3}$ & $\begin{array}{c}\alpha_{0} \\
(\mathrm{xE}-05) \\
\end{array}$ & $\alpha_{1}$ & $\alpha_{2}$ & $\beta_{1}$ & $\beta_{2}$ & $\begin{array}{c}\gamma_{1} \\
(\mathrm{xE}-05)\end{array}$ & $\gamma_{2}$ & $\gamma_{3}$ \\
\hline \multicolumn{13}{|c|}{ Panel A: Stocks with ISF Introduction Date of 16 May, 1994} \\
\hline BHP & $\begin{array}{c}0.0002 \\
(1.34) \\
\end{array}$ & $\begin{array}{c}-0.0005 \\
(2.02) \\
\end{array}$ & $\begin{array}{l}1.2266 \\
(60.9)\end{array}$ & $\begin{array}{c}0.0323 \\
(1.06) \\
\end{array}$ & $\begin{array}{r}0.3450 \\
(3.94) \\
\end{array}$ & $\begin{array}{c}0.1252 \\
(4.31) \\
\end{array}$ & $\begin{array}{c}-0.0643 \\
(2.08) \\
\end{array}$ & $\begin{array}{c}0.8389 \\
(27.7)\end{array}$ & $\begin{array}{c}0.0718 \\
(2.25)\end{array}$ & $\begin{array}{c}-0.2510 \\
(2.75) \\
\end{array}$ & $\begin{array}{c}-0.0922 \\
(3.01)\end{array}$ & $\begin{array}{r}0.0417 \\
(2.29) \\
\end{array}$ \\
\hline NAB & $\begin{array}{c}0.0003 \\
(1.24) \\
\end{array}$ & $\begin{array}{c}0.0001 \\
(0.12) \\
\end{array}$ & $\begin{array}{c}0.9898 \\
(35.9) \\
\end{array}$ & $\begin{array}{c}-0.0077 \\
(0.17) \\
\end{array}$ & $\begin{array}{l}1.0500 \\
(3.53) \\
\end{array}$ & $\begin{array}{c}0.0224 \\
(1.36) \\
\end{array}$ & $\begin{array}{c}0.0754 \\
(3.79) \\
\end{array}$ & $\begin{array}{c}0.8121 \\
(17.2) \\
\end{array}$ & $\begin{array}{r}0.1165 \\
(2.43) \\
\end{array}$ & $\begin{array}{c}-0.7940 \\
(2.64) \\
\end{array}$ & $\begin{array}{r}0.0439 \\
(1.52) \\
\end{array}$ & $\begin{array}{c}-0.0973 \\
(7.75) \\
\end{array}$ \\
\hline NCP & $\begin{array}{c}0.0003 \\
(0.76)\end{array}$ & $\begin{array}{c}-0.0001 \\
(0.28)\end{array}$ & $\begin{array}{l}1.4901 \\
(29.5)\end{array}$ & $\begin{array}{c}-0.2927 \\
(4.10)\end{array}$ & $\begin{array}{l}1.4900 \\
(6.17)\end{array}$ & $\begin{array}{c}0.0776 \\
(6.08)\end{array}$ & $\begin{array}{c}0.0307 \\
(0.96)\end{array}$ & $\begin{array}{l}0.8347 \\
(70.1)\end{array}$ & $\begin{array}{c}-0.0964 \\
(1.75)\end{array}$ & $\begin{array}{l}1.7200 \\
(2.08)\end{array}$ & $\begin{array}{c}0.1336 \\
(7.70)\end{array}$ & $\begin{array}{c}-0.0140 \\
(0.36)\end{array}$ \\
\hline $\begin{array}{l}\text { Control } \\
\text { Portfolio }\end{array}$ & $\begin{array}{c}0.0001 \\
(0.79) \\
\end{array}$ & $\begin{array}{c}0.0001 \\
(0.22) \\
\end{array}$ & $\begin{array}{c}0.8510 \\
(41.6) \\
\end{array}$ & $\begin{array}{c}0.1426 \\
(5.57) \\
\end{array}$ & $\begin{array}{c}2.2300 \\
(6.29) \\
\end{array}$ & $\begin{array}{r}0.0831 \\
(3.24) \\
\end{array}$ & $\begin{array}{l}0.0029 \\
(0.072) \\
\end{array}$ & $\begin{array}{c}0.3264 \\
(3.59) \\
\end{array}$ & $\begin{array}{r}0.5347 \\
(5.13) \\
\end{array}$ & $\begin{array}{c}-1.9900 \\
(5.38) \\
\end{array}$ & $\begin{array}{c}0.1455 \\
(2.48) \\
\end{array}$ & $\begin{array}{c}-0.0600 \\
(1.89) \\
\end{array}$ \\
\hline \multicolumn{13}{|c|}{ Panel B: Stocks with ISF Introduction Date of 26 September, 1994} \\
\hline MIM & $\begin{array}{l}0.0001 \\
(0.00) \\
\end{array}$ & $\begin{array}{c}-0.0015 \\
(2.21) \\
\end{array}$ & $\begin{array}{l}1.4681 \\
(32.4)\end{array}$ & $\begin{array}{c}-0.1533 \\
(1.98)\end{array}$ & $\begin{array}{r}2.4400 \\
(5.97) \\
\end{array}$ & $\begin{array}{c}0.0486 \\
(2.84)\end{array}$ & $\begin{array}{c}-0.0596 \\
(3.39) \\
\end{array}$ & $\begin{array}{c}0.8153 \\
(29.7)\end{array}$ & $\begin{array}{c}0.1588 \\
(5.70) \\
\end{array}$ & $\begin{array}{c}-2.0700 \\
(4.94) \\
\end{array}$ & $\begin{array}{c}0.0526 \\
(1.87) \\
\end{array}$ & $\begin{array}{c}0.0542 \\
(6.08) \\
\end{array}$ \\
\hline WBC & $\begin{array}{c}-0.0004 \\
(1.31) \\
\end{array}$ & $\begin{array}{c}0.0010 \\
(2.23) \\
\end{array}$ & $\begin{array}{l}1.2750 \\
(29.6) \\
\end{array}$ & $\begin{array}{c}-0.2527 \\
(4.43) \\
\end{array}$ & $\begin{array}{r}5.3400 \\
(3.01) \\
\end{array}$ & $\begin{array}{c}0.1076 \\
(3.02) \\
\end{array}$ & $\begin{array}{c}-0.0013 \\
(0.02) \\
\end{array}$ & $\begin{array}{c}0.5440 \\
(3.80) \\
\end{array}$ & $\begin{array}{c}0.2660 \\
(1.75) \\
\end{array}$ & $\begin{array}{c}-4.2400 \\
(2.34) \\
\end{array}$ & $\begin{array}{c}-0.0631 \\
(1.85) \\
\end{array}$ & $\begin{array}{c}-0.0385 \\
(1.37) \\
\end{array}$ \\
\hline WMC & $\begin{array}{c}-0.0001 \\
(0.32)\end{array}$ & $\begin{array}{c}-0.0008 \\
(1.57)\end{array}$ & $\begin{array}{l}1.2523 \\
(31.6)\end{array}$ & $\begin{array}{c}0.0290 \\
(0.48)\end{array}$ & $\begin{array}{c}3.5800 \\
(7.47)\end{array}$ & $\begin{array}{c}0.0841 \\
(2.84)\end{array}$ & $\begin{array}{c}-0.0761 \\
(2.34)\end{array}$ & $\begin{array}{l}0.6846 \\
(16.6)\end{array}$ & $\begin{array}{c}0.2529 \\
(5.77)\end{array}$ & $\begin{array}{c}-3.2700 \\
(6.58)\end{array}$ & $\begin{array}{c}0.0282 \\
(0.74)\end{array}$ & $\begin{array}{c}0.0770 \\
(3.62)\end{array}$ \\
\hline $\begin{array}{l}\text { Control } \\
\text { Portfolio }\end{array}$ & $\begin{array}{l}-0.001 \\
(0.09)\end{array}$ & $\begin{array}{c}0.0003 \\
(0.12)\end{array}$ & $\begin{array}{c}0.8546 \\
(42.9)\end{array}$ & $\begin{array}{c}0.0349 \\
(0.11)\end{array}$ & $\begin{array}{c}0.3500 \\
(5.84)\end{array}$ & $\begin{array}{c}0.0356 \\
(3.10)\end{array}$ & $\begin{array}{c}-0.1003 \\
(1.86)\end{array}$ & $\begin{array}{c}0.8486 \\
(40.8)\end{array}$ & $\begin{array}{c}0.0505 \\
(0.11)\end{array}$ & $\begin{array}{c}-0.4610 \\
(0.39)\end{array}$ & $\begin{array}{l}0.0762 \\
(3.12)\end{array}$ & $\begin{array}{c}0.0952 \\
(1.07)\end{array}$ \\
\hline
\end{tabular}
control portfolio. 
TABLE 3 (Continued)

Estimated Augmented Market / Generalised TARCH Model Coefficients

\begin{tabular}{|c|c|c|c|c|c|c|c|c|c|c|c|c|}
\hline \multirow{2}{*}{ Stock } & \multicolumn{4}{|c|}{ Mean Equation } & \multicolumn{8}{|c|}{ Variance Equation } \\
\hline & $\phi_{0}$ & $\phi_{1}$ & $\phi_{2}$ & $\phi_{3}$ & $\begin{array}{c}\alpha_{0} \\
(\mathrm{xE}-05)\end{array}$ & $\alpha_{1}$ & $\alpha_{2}$ & $\beta_{1}$ & $\beta_{2}$ & $\begin{array}{c}\gamma_{1} \\
(\mathrm{xE}-05) \\
\end{array}$ & $\gamma_{2}$ & $\gamma_{3}$ \\
\hline \multicolumn{13}{|c|}{ Panel C: Stocks with ISF Introduction Date of 13 March, 1995} \\
\hline ANZ & $\begin{array}{c}-0.0003 \\
(0.95) \\
\end{array}$ & $\begin{array}{c}0.0006 \\
(1.22) \\
\end{array}$ & $\begin{array}{l}1.3351 \\
(32.9) \\
\end{array}$ & $\begin{array}{c}-0.0534 \\
(0.93) \\
\end{array}$ & $\begin{array}{c}8.2800 \\
(4.82) \\
\end{array}$ & $\begin{array}{c}0.1064 \\
(4.28) \\
\end{array}$ & $\begin{array}{c}0.1048 \\
(1.71) \\
\end{array}$ & $\begin{array}{c}0.3712 \\
(3.05) \\
\end{array}$ & $\begin{array}{c}0.2330 \\
(1.61) \\
\end{array}$ & $\begin{array}{c}-5.8500 \\
(3.22) \\
\end{array}$ & $\begin{array}{c}-0.0015 \\
(0.03) \\
\end{array}$ & $\begin{array}{c}-0.0336 \\
(0.59) \\
\end{array}$ \\
\hline RIO & $\begin{array}{c}0.0001 \\
(0.34)\end{array}$ & $\begin{array}{c}-0.0005 \\
(1.31) \\
\end{array}$ & $\begin{array}{l}1.2452 \\
(46.7)\end{array}$ & $\begin{array}{c}-0.1057 \\
(2.53) \\
\end{array}$ & $\begin{array}{c}0.7250 \\
(4.24) \\
\end{array}$ & $\begin{array}{l}0.0480 \\
(2.69)\end{array}$ & $\begin{array}{c}0.0330 \\
(1.04) \\
\end{array}$ & $\begin{array}{c}0.8469 \\
(27.8)\end{array}$ & $\begin{array}{c}-0.0106 \\
(0.20) \\
\end{array}$ & $\begin{array}{c}-0.1050 \\
(0.39) \\
\end{array}$ & $\begin{array}{c}0.0393 \\
(1.73) \\
\end{array}$ & $\begin{array}{c}0.0403 \\
(1.13) \\
\end{array}$ \\
\hline FBG & $\begin{array}{c}-0.0005 \\
(1.22)\end{array}$ & $\begin{array}{c}0.0008 \\
(1.51)\end{array}$ & $\begin{array}{l}1.2641 \\
(27.5)\end{array}$ & $\begin{array}{c}-0.4223 \\
(6.62)\end{array}$ & $\begin{array}{l}1.9600 \\
(8.75)\end{array}$ & $\begin{array}{c}0.0394 \\
(2.67)\end{array}$ & $\begin{array}{c}-0.0032 \\
(0.17)\end{array}$ & $\begin{array}{c}0.8448 \\
(58.7)\end{array}$ & $\begin{array}{c}0.1258 \\
(6.76)\end{array}$ & $\begin{array}{c}-1.9000 \\
(8.08)\end{array}$ & $\begin{array}{c}0.0965 \\
(4.19)\end{array}$ & $\begin{array}{c}-0.0199 \\
(1.28)\end{array}$ \\
\hline $\begin{array}{l}\text { Control } \\
\text { Portfolio }\end{array}$ & $\begin{array}{l}1.8400 \\
(0.09)\end{array}$ & $\begin{array}{l}0.0002 \\
(0.91)\end{array}$ & $\begin{array}{l}0.849 \\
(38.8)\end{array}$ & $\begin{array}{c}0.1442 \\
(5.32)\end{array}$ & $\begin{array}{c}0.2930 \\
(2.90)\end{array}$ & $\begin{array}{l}0.0504 \\
(2.26)\end{array}$ & $\begin{array}{c}0.0206 \\
(0.49)\end{array}$ & $\begin{array}{c}0.8815 \\
(23.0)\end{array}$ & $\begin{array}{c}-0.0760 \\
(0.67)\end{array}$ & $\begin{array}{c}0.0882 \\
(0.33)\end{array}$ & $\begin{array}{c}-0.0476 \\
(1.87)\end{array}$ & $\begin{array}{c}-0.0522 \\
(1.38)\end{array}$ \\
\hline \multicolumn{13}{|c|}{ Panel D: Stock with ISF Introduction Date of 18 October, 1995} \\
\hline PDP & $\begin{array}{c}-0.0005 \\
(1.96) \\
\end{array}$ & $\begin{array}{c}-0.0001 \\
(0.14) \\
\end{array}$ & $\begin{array}{l}1.0771 \\
(41.8) \\
\end{array}$ & $\begin{array}{c}-0.0820 \\
(1.31) \\
\end{array}$ & $\begin{array}{r}1.1900 \\
(7.09) \\
\end{array}$ & $\begin{array}{c}0.0532 \\
(3.79) \\
\end{array}$ & $\begin{array}{c}0.0251 \\
(0.66) \\
\end{array}$ & $\begin{array}{c}0.7928 \\
(37.7) \\
\end{array}$ & $\begin{array}{c}0.0143 \\
(0.30) \\
\end{array}$ & $\begin{array}{c}0.5560 \\
(0.93) \\
\end{array}$ & $\begin{array}{c}0.0969 \\
(3.98) \\
\end{array}$ & $\begin{array}{r}0.0609 \\
(1.53) \\
\end{array}$ \\
\hline $\begin{array}{l}\text { Control } \\
\text { Portfolio }\end{array}$ & $\begin{array}{c}0.0001 \\
(0.48)\end{array}$ & $\begin{array}{c}-0.0003 \\
(0.24)\end{array}$ & $\begin{array}{c}0.8719 \\
(49.5)\end{array}$ & $\begin{array}{c}0.1068 \\
(0.52)\end{array}$ & $\begin{array}{c}0.3960 \\
(6.43)\end{array}$ & $\begin{array}{c}0.0659 \\
(4.35)\end{array}$ & $\begin{array}{c}0.0376 \\
(0.17)\end{array}$ & $\begin{array}{l}0.824 \\
(38.3)\end{array}$ & $\begin{array}{c}0.0918 \\
(0.24)\end{array}$ & $\begin{array}{c}-0.6800 \\
(3.77)\end{array}$ & $\begin{array}{c}0.0180 \\
(0.85)\end{array}$ & $\begin{array}{l}0.0806 \\
(0.151)\end{array}$ \\
\hline
\end{tabular}


TABLE 4

\section{Variance Equation Joint Hypothesis Tests P-Values}

This table reports p-values associated with Wald tests of the null hypotheses in the model:

$$
\begin{aligned}
& \mathrm{R}_{\mathrm{it}}=\phi_{0}+\phi_{1} \mathrm{D}_{1}+\phi_{2} \mathrm{R}_{\mathrm{Mt}}+\phi_{3} \mathrm{D}_{1} \mathrm{R}_{\mathrm{Mt}}+\varepsilon_{\mathrm{t}} \\
& \mathrm{h}_{\mathrm{t}}=\alpha_{0}+\alpha_{1} \varepsilon_{\mathrm{t}-1}^{2}+\alpha_{2} \mathrm{D}_{1} \varepsilon_{\mathrm{t}-1}^{2}+\beta_{1} \mathrm{~h}_{\mathrm{t}-1}+\beta_{2} \mathrm{D}_{1} \mathrm{~h}_{\mathrm{t}-1}+\gamma_{1} \mathrm{D}_{1}+\gamma_{2} \varepsilon_{\mathrm{t}-1}^{2} \mathrm{D}_{2}+\gamma_{3} \varepsilon_{\mathrm{t}-1}^{2} \mathrm{D}_{3}
\end{aligned}
$$

where $\mathrm{R}_{\mathrm{t}}$ is the $\log$ price relative of the underlying equity of stock $i$ (on which an ISF has been introduced) at time period $t ; \mathrm{D}_{1}$ is a dummy variable which takes on a value of unity following the introduction of that share's ISF; $\mathrm{D}_{2}\left(\mathrm{D}_{3}\right)$ is a dummy variable which takes on a value of unity if the mean equation error term is negative in the pre (post) ISF introduction period and zero otherwise and $\mathrm{R}_{\mathrm{Mt}}$ is the log price relative of the Australian stock market index. The mo del is also estimated at each date for

\begin{tabular}{|c|c|c|c|}
\hline \multirow{2}{*}{ Stock } & \multicolumn{3}{|c|}{ Null Hypothesis } \\
\hline & $\alpha_{2}=\beta_{2}=0$ & $\gamma_{1}=\alpha_{2}=\beta_{2}=0$ & $\gamma_{2}=\gamma_{3}$ \\
\hline \multicolumn{4}{|c|}{ Panel A: Stocks with ISF Introduction Date of 16 May, 1994} \\
\hline BHP & 0.0627 & 0.0117 & 0.0000 \\
\hline NAB & 0.0000 & 0.0000 & 0.0000 \\
\hline $\mathrm{NCP}$ & 0.1036 & 0.1080 & 0.0000 \\
\hline Control Portfolio & 0.0000 & 0.0000 & 0.0019 \\
\hline \multicolumn{4}{|c|}{ Panel B: Stocks with ISF Introduction Date of 26 September, 1994} \\
\hline MIM & 0.0000 & 0.0000 & 0.9650 \\
\hline WBC & 0.0972 & 0.0016 & 0.5630 \\
\hline WMC & 0.0000 & 0.0000 & 0.2870 \\
\hline Control Portfolio & 0.1184 & 0.0019 & 0.8330 \\
\hline \multicolumn{4}{|c|}{ Panel C: Stocks with ISF Introduction Date of 13 March, 1995} \\
\hline ANZ & 0.0090 & 0.0000 & 0.5900 \\
\hline RIO & 0.5218 & 0.5111 & 0.9270 \\
\hline FBG & 0.0000 & 0.0000 & 0.0000 \\
\hline Control Portfolio & 0.7928 & 0.2923 & 0.9190 \\
\hline \multicolumn{4}{|c|}{ Panel D: Stock with ISF Introduction Date of 18 October, 1995} \\
\hline PDP & 0.6675 & 0.0030 & 0.4660 \\
\hline Control Portfolio & 0.6792 & 0.0007 & 0.9060 \\
\hline
\end{tabular}
an equally weighted control portfolio. 


\section{References}

Antoniou, A. and Holmes, P., (1995), "Futures Trading, Information and Spot Price Volatility: Evidence for the FTSE-100 Stock Index Futures Contract Using GARCH", Journal of Banking and Finance, Vol.19, pp.117-129.

Antoniou, A., Holmes, P. and Priestley, R., (1998), “The Effects of Stock Index Futures Trading on Stock Index Volatility: An Analysis of the Asymmetric Response of Volatility to News", Journal of Futures Markets, Vol.18, pp.151-166.

Arditti, F. and John, K., (1980), "Spanning the State Space with Options", Journal of Financial and Quantitative Analysis, Vol.15, pp.1-9.

Bansal, V., Pruitt, S. and Wei, J., K., (1989), "An Empirical Reexamination of the Impact of CBOE Option Initiation on the Volatility and Trading Volume of the Underlying Equities: 1973-1986”, Financial Review, Vol.24, pp.19-29.

Bekaert, G. and Wu, G., (2000), "Asymmetric Volatility and Risk in Equity Markets", Review of Financial Studies, forthcoming.

Bera, A. and Higgins, M., (1993), “ARCH Models: Properties, Estimation and Testing”, Journal of Economic Surveys, Vol. 7, pp. 305-362.

Bessembinder, H. and Seguin, P., (1992), "Futures-Trading Activity and Stock Price Volatility”, Journal of Finance, Vol.47, pp.2015-2034.

Bollen, N., (1998), "A Note on the Impact of Options on Stock Return Volatility", Journal of Banking and Finance, Vol.22, pp.1181-1191.

Bollerslev, T., Chou, R.Y. and Kroner, K.F. (1992), "ARCH Modelling in Finance: A Review of the Theory and Empirical Evidence" Journal of Econometrics, Vol.52, pp.6190.

Bollerslev, T. and Mikkelsen, H. (1996) "Modelling and Pricing Long Memory in Stock Market Volatility’ Journal of Econometrics, Vol 73, pp. 151 - 184.

Brailsford, T.J. and Cusack, A.J., (1997), "A Comparison of Futures Pricing Models in a New Market: The Case of Individual Share Futures", Journal of Futures Markets, Vol.17, pp.515-541.

Breeden, D. and Litzenberger, R., (1978), "Prices of State-Contingent Claims Implicit in Option Prices", Journal of Business, Vol.51, pp.621-652.

Choi, H. and Subrahmanyam, A., (1994), "Using Intraday Data to Test for Effects of Index Futures on the Underlying Markets", Journal of Futures Markets, Vol.14, pp.293-322. 
Conrad, J., (1989), “The Price Effect of Option Introduction”, Journal of Finance, Vol.44, pp.487-498.

Cox, C., (1976), "Futures Trading and Market Information", Journal of Political Economy, Vol.84, pp.1215-1237.

Damodaran, A., (1990), "Index Futures and Stock Market Volatility", Review of Futures Markets, Vol.9, pp. 442-457.

Damodaran, A. and Lim, J., (1991), "The Effects of Option Listing on the Underlying Stocks' Return Processes", Journal of Banking and Finance, Vol.15, pp.647-664.

Damodaran, A. and Subrahmanyam, M., (1992), "The Effects of Derivative Securities on the Markets for the Underlying Assets in the United States: A Survey", Financial Markets, Institutions and Instruments, Vol., pp.1-21.

Edwards, F., (1988a), "Futures Trading and Cash Market Volatility: Stock Index and Interest Rate Futures", Journal of Futures Markets, Vol.8, pp.421-439.

Edwards, F., (1988b), "Does Futures Trading Increase Stock Market Volatility?", Financial Analysts Journal, Vol.44, pp.63-69.

Figlewski, S., (1981), "Futures Trading and Volatility in the GNMA Market", Journal of Finance, Vol.36, pp.445-456.

Hakansson, N., (1978), "Welfare Aspects of Options and Supershares", Journal of Finance, Vol.33, pp.759-776.

Harris, L., (1989), “S\&P 500 Cash Stock Price Volatilities”, Journal of Finance, Vol.44, pp.1155-1176.

Hodgson, A. and Nicholls, D., (1991), "The Impact of Index Futures Markets on Australian Sharemarket Volatility", Journal of Business Finance and Accounting, Vol.18, pp.267279.

Kamara, A., Miller, T. and Siegel, A., (1992), "The Effect of Futures Trading on the Stability of Standard and Poor 500 Returns", Journal of Futures Markets, Vol.12, pp.645-658.

Kan, A. and Tang, G., (1999), "The Impact of Index Futures Trading on the Betas of the Underlying Constituent Stocks: The Case of Hong Kong”, Journal of International Financial Markets, Institutions and Money, Vol. 9, pp. 97-114.

Klemkosky, R. and Maness, T., (1980), "The Impact of Options on the Underlying Securities", Journal of Portfolio Management, Winter, pp. 12-18. 
Lee, S. and Ohk, K., (1992), "Stock Index Futures Listing and Structural Change in TimeVarying Volatility", Journal of Futures Markets, Vol.12, pp.493-509.

Ma, C. and Rao, R., (1988), "Information Asymmetry and Option Trading", Financial Review, Vol.23, pp.39-51.

Martin, J. and Senchack, A., (1989), "Program Trading and Systematic Stock Price Behaviour", Financial Analysts Journal, May-June, pp. 61-67.

Martin, J. and Senchack, A., (1991), "Index Futures, Program Trading, and the Covariability of the Major Index Stocks", Journal of Futures Markets, Vol. 11, pp. 95111.

Miller, M.H., (1993), "The Economics and Politics of Index Arbitrage in the US and Japan", Pacific-Basin Finance Journal, Vol.1, pp.3-11.

Moriarty, E. and Tosini, P., (1985), "Futures Trading and Price Volatility of GNMA Certificates - Further Evidence", Journal of Futures Markets, Vol.5, pp.633-641.

Nelson, D.B. (1990a) "Stationarity and Persistence in the $\operatorname{GARCH}(1,1)$ Model" Econometric Reviews, Vol.6, pp.318-334.

Nelson, D.B. (1990b) “ARCH models as Diffusion Approximations" Journal of Econometrics, Vol.45, pp.7-38.

Powers, M., (1970), "Does Futures Trading Reduce Price Fluctuations in the Cash Markets?", American Economic Review, Vol.60, pp.460-464.

Robinson, G., (1994), "The Effects of Futures Trading on Cash Market Volatility: Evidence from the London Stock Exchange", Review of Futures Markets, Vol.13, pp.429-452.

Ross, S., (1977), “Options and Efficiency”, Quarterly Journal of Economics, Vol.4, pp.129-176.

Schwert, G.W., (1990), "Stock Market Volatility", Financial Analysts Journal, Vol.46, pp.23-34.

Skinner, D., (1989), “Options Markets and Stock Return Volatility”, Journal of Financial Economics, Vol.24, pp.61-78.

Sorescu, S., (2000), "The Effect of Options on Stock Prices: 1973 to 1995”, Journal of Finance, forthcoming.

Stein, J., (1987), "Informational Externalities and Welfare-Reducing Speculation", Journal of Political Economy, Vol.95, pp.1123-1145. 
Stein, J., (1989), “Overreactions in Options Markets”, Journal of Finance, Vol.44, pp.1011-1023.

Stoll, H. and Whaley, R., (1987), "Expiration Day Effects of Index Options and Futures", Financial Analysts Journal, Vol.43, pp.16-28.

Trennepohl, G. and Dukes, W., (1979), "CBOE Options and Stock Volatility”, Review of Business and Economic Research, Vol. 8, pp. 36-48.

Watt, W., Yadav, P. and Draper, P., (1992), "The Impact of Option Listing on Underlying Stock Returns: The UK Evidence", Journal of Business Finance And Accounting, Vol.19, pp.485-503.

Whiteside, M., Dukes, W. and Dunne, P., (1983), "Short Term Impact of Option Trading on the Underlying Securities", Journal of Financial Research, Vol. 6, pp. 313-321.

Working, H., (1960), "Price Effects of Futures Trading", Food Research Institute Studies, Vol.1, pp.3-31.

Zakoian, J-M., (1994), "Threshold Heteroskedastic Models", Journal of Economic Dynamics and Control, Vol. 18, pp. 931-995. 